\title{
The Pedagogical Competence Skills of Biology Teacher Candidates
}

\author{
Kukuh Munandar ${ }^{1,2}$, Muslimin Ibrahim ${ }^{3}$, Leny Yuanita ${ }^{3}$ \\ ${ }^{1}$ Postgraduate Program of Science Education, Universitas Negeri Surabaya (UNESA),Indonesia \\ ${ }^{2}$ Biology Education of Universitas Muhammadiyah Jember, Indonesia \\ ${ }^{3}$ Science Education Postgraduate Program of Universitas Negeri Surabaya-Indonesia. \\ 1,2kukuhmunandar@mhs.unesa.ac.id \\ ${ }^{3}$ musliminibrahim@unesa.ac.id \\ ㄹenyyuanita@unesa.ac.id
}

\begin{abstract}
The research on "Pedagogical Competence Skills of Biology Teacher Candidates" aims to identify the pedagogical competence profile of biology teacher candidates in biology learning to prepare them in this $21^{\text {st }}$ century. The results of the research are used as: 1) suggestion for stakeholders to improve pedagogical competence of biology teacher candidates, 2) reflection of learning in the department of Biology Education, and 3) recommendation for further research in the development and empowerment of prospective teachers, especially biology teacher. To achieve these goals, this research uses qualitative research method with quantitative descriptive analysis. The data collection instruments are: 1) pedagogical self-evaluation questionnaire, 2) assessment sheets of learning device, 3) assessment sheets of teaching learning process, and 4) teachers' self-confidence assessment sheets. Based on the data analysis, it can be concluded that the category of pedagogical ability of the students of biology teacher candidates in the assessment is very good ( $\dot{x}=3.77$ scale 4). Meanwhile, the category of the self-evaluation assessment of prospective biology teacher students is good ( $x$

$\dot{x}=3.87$ scale 5). However, the category of the use of ICT-based learning media is enough $(\dot{x}=2.2$ scale 5$)$.
\end{abstract}

Keywords: pedagogical competence skills; biology teacher candidates; $21^{\text {st }}$ century; selfevaluation

\section{Introduction}

The significant skills needed by the $21^{\text {st }}$ century world occupational demands are problem solving, communication, cooperation, learning skills, critical thinking, ethics, technical skills and creativity of working [1]. These are in line with the frame work of $21 \mathrm{st}$ Century Learning [2] explaining that the learning and innovation skills that students need for an increasingly complex life and work environment in the $21^{\text {st }}$ century world are: 1) Creativity and Innovation, 2) Critical Thinking and Problem Solving, and 3) Communication and Collaboration. Therefore schools and colleges must prepare students to understand and handle global issues. Teachers and lecturers should re-examine their curriculum and teaching strategies so that all students can flourish in a global and interdependent society. Therefore, 
teachers must be equipped by changing how they guide students in learning (pedagogy). Wellprepared teachers and motivated teachers are the most important variables in the successful learning [3]. The forms of participatory education by applying active learning methods and cooperative learning are indispensable [4].

The tenth article of Law no. 14/2005 mandates that teachers should have four competencies, namely: 1) pedagogical competence, 2) personality competence, 3) social competence, and 4) professional competence [5]. The key that every teacher should have in teaching is pedagogical competence. Pedagogical competence is a set of science and teaching skills of teachers in carrying out their professional duties as a teacher so that the goal of education can be achieved well. Pedagogical competence is basically the ability of teachers in managing the learners' learning. Pedagogical competence is a distinctive competency which will differentiate teachers with other professions and will determine the level of success of the learning process and learners' outcomes. This pedagogical competence is not obtained suddenly. It can be obtained through continuous and systematic learning whether during preservice (teacher education) and during the position (already a teacher) supported by other talents, interests as well as other potential teacher skills of each individual.

Therefore, students of biology teacher candidate are expected to be able to plan biology learning based on practice/inquiry or innovative, to facilitate student learning, to assess student learning, and to create learning community for students. The prospective biology teachers should have basic teaching skills, biology teaching strategies and methodologies. They should interact with students to improve learning and learning outcomes. Moreover, they need to implement effective classroom organizations, use technological developments to improve learning processes, and use early conceptions and student interest to learn new concepts [6].

In the $21^{\text {st }}$ century, the use of information and communication technology (ICT) has penetrated into all areas of activity. Therefore, integrated ICT pedagogical competencies in the $21^{\text {st }}$ century are necessary to provide 21 st century skills. For that, prospective biology teachers need to be taught to develop innovative pedagogical competencies integrated with ICTs related to professional teachers, they are: i) integrating ICT into practice teaching of science, ii) promoting and exploring interaction practices when planning pedagogical activities (for formal and/or non-formal contexts), iii) developing collaborative work, and iv) developing research competencies [7].

The teaching of science-biological content as part of the science concept will be integrated with ICT (Information and Communication Technology). This is in accordance with 21st century learning which are: 1) Dynamic, 2) Demanding, and 3) Directed [3]. In addition, ICT provides a new teaching-learning environment and approach. [8] It helps to understand the concept of science and the interpretation of natural phenomena without aiming to replace experimental activities [9]. Moreover, working with ICT is recognized as one of the key competencies needed for success in life and competition in the labour market [10].

\section{Experimental}

The research is a descriptive quantitative research. It was started from September until November 2017. The object of research is the six students of Biology Education (Biology 
teacher candidates) Faculty of Teacher Training and Education, Muhammadiyah Jember University

The data collection instruments which are used are: 1) pedagogical questionnaire by using self evaluation. It consists of: i) assessment need, ii) plan, iii) implantation and monitoring, iv) evaluation, and v) the use of ICT towards learning activity, adopted from [12], 2) Pedagogical assessment sheet which is done by two senior Biology teachers. It consists of: i) the arranged learning media, ii) the process of teaching and learning, and iii) the stalwart of self-confidence as a teacher, adopted from [11].

The data are in the form of scores resulted from the questionnaire consisting of the Biology teacher candidate student's answers and the assessment from two senior Biology teachers. Furthermore, the data were analyzed by using descriptive quantitative method.

\section{Results And Discussion}

\section{III.1 Pedagogical Scores Based on Self-Evaluation}

Based on the self-evaluation (self-assessing) of biology teacher candidates, it can be known that the average score is 3.87 (very good category). The score of each student biology teacher candidates is as follows: 1) biology teacher candidate 1 is 3.85 (very good), 2) biology teacher candidate 2 is 3.9 (very good), 3) biology teacher candidate 3 is 3.85 (very good), 4) biology teacher candidate 4 is 3.7 (very good), 5) biology teacher candidate 5 is 3.4 (very good), and 6) biology teacher candidate 6 is 3.6 (very good) (Table 1).

Based on the self-evaluation (self-assessing) in the stage of learning cycle, (or pedagogical per stage) the averages are as follows: 1) assessing the need for learning is 4.175 (very good), 2) planning is 4.0 (good) 3) implementation and monitoring are 3.79 (good), 4) evaluation is 3.5 (good), and the use of ICT on learning is 2.2 (enough) (Table 2).

Table 1. Pedagogical Scores Based on Self Evaluation

\begin{tabular}{cc}
\hline The Names of Biology Teacher Candidate & The Average Scores of lesson plan \\
\hline The teacher candidate student 1 & 3,85 \\
\hline The teacher candidate student 2 & 3,9 \\
\hline The teacher candidate student 3 & 3,85 \\
\hline The teacher candidate student 4 & 3,7 \\
\hline The teacher candidate student 5 & 3,4 \\
\hline The teacher candidate student 6 & 3,6 \\
\hline The information: & \\
$1,0-2,0=$ enough & \\
$2,1-3.0=$ good & \\
$3,1-4,0=$ very good &
\end{tabular}

Table 2. Pedagogical Scores per Stages

\begin{tabular}{ccc}
\hline The Stages & The Average Scores & The Categories \\
\hline Assessing the need for learning & 4,175 & Very good \\
\hline Planning & 4,0 & Good \\
\hline Implementation \& Monitoring & 3,79 & Good \\
\hline Evaluation & 3,5 & Good \\
\hline
\end{tabular}




\begin{tabular}{l} 
Using ICT \\
\hline The information: \\
$1.0-2.0=$ less \\
$2.1-3.0=$ enough \\
$3.1-4.0=$ good \\
$4.1-5,0=$ very good
\end{tabular}

The pedagogical ability by using self-evaluation of biology teacher candidate students is $\operatorname{good}(\dot{x}=3.87$ with scale 5). [11]It is said that the learning process of preparing students with 21 st century skills demands teacher readiness in planning, implementing and evaluating learning. Similarly, the findings above are not much different from the research [12] which says that the average of pedagogical ability biology of teachers in Jember is 3.86 (or good category).

Apart from good pedagogic ability in biology teacher candidate students, there are still shortcomings in the use of ICT-based learning media. It is said that based on the selfevaluation done by biology teacher candidate, the use of ICT-based learning media average is only $\dot{x}=2.2$ (or enough category). This shows that the use of ICT-based learning media is still weak or unfamiliar. It is also reported that pre-service teachers are not compatible with all knowledge domains and pedagogical content knowledge (PCK) that enable a teacher to teach well [13]. The teacher candidate students do not feel ready to effectively use technology in their classrooms [14].

ICT integration is the use of ICTs that support and improve the achievement of teaching [15], [16] and learning goals which effectively integrated and bring change in education [16]. Therefore, schools should integrate their curriculum by using technology as a tool for teaching and learning, so students will have an authentic and relevant learning experience [17]. Technology is not just an add-on (supplementary skills). A teacher candidate should not only assume that it is only required in the classroom, they need to make lesson plans and tasks integrated in technology and reflect it in the classroom [18]. Teacher candidates should learn to use everyday teaching tools, such as projectors, internet, video and so on [14], [17]. By using technology, learning process will be more efficient and help them finding the resources which they are looking for quickly. The key to success for teacher candidates in integrating technology in their learning is by always using the technology.

\subsection{The Scores of Lesson Plans}

The average score for the preparation of the lesson plan is 3.85 (or very good category). The average scores of the lesson plan of each biology teacher candidate students are: 1) The teacher candidate student 1 is 3,$64 ; 2$ ) The teacher candidate student 2 is 3,$86 ; 3$ ) The teacher candidate student 3 is 4 ; 4) The teacher candidate student 4 is 3.86 ; 5) The teacher candidate student 5 is 3.93; and 6) The teacher candidate student 6 is 3.79 (Table 3).

Table 3. The Scores of Learning Implementation Plan

\begin{tabular}{cccc}
\hline & \multicolumn{3}{c}{ The Scores of lesson plan } \\
\cline { 2 - 4 } THE NAMES OF BIOLGY TEACHER CANDIDATE & \multirow{2}{*}{$\mathbf{1}^{\text {st }}$ Expert } & \multirow{2}{*}{$\mathbf{2}^{\text {nd }}$ Expert } & \multirow{2}{*}{ The Average Scores } \\
\hline Teacher candidate student 1 & 3,71 & 3,57 & 3,64 \\
\hline Teacher candidate student 2 & 3,86 & 3,86 & 3,86 \\
\hline
\end{tabular}




\begin{tabular}{cccc}
\hline Teacher candidate student 3 & 4 & 4 & 4 \\
\hline Teacher candidate student 4 & 3,71 & 4 & 3,86 \\
\hline Teacher candidate student 5 & 3,86 & 4 & 3,93 \\
\hline Teacher candidate student 6 & 3,86 & 3,71 & 3,79 \\
\hline The Average & 3,83 & 3,86 & 3,85 \\
\hline
\end{tabular}

The information:

$1,0-2,0=$ enough

$2,1-3.0=$ good

$3,1-4,0=$ very good

The ability to arrange the learning implementation plan of biology teacher candidates is $\dot{x}=3.85$ in which the learning process for preparing students in the 21 st century skills requires teacher preparedness in planning, implementing, and evaluating learning [11] [12].

\subsection{The Score of Learning Implementation}

The average score of practice teaching for learning implementation (teaching and learning activities) is 3.68 (or very good category)in which the average score of teaching and learning activities of each biology teacher candidate student is as follows: 1) teacher candidate student 1 is $3.59 ; 2$ ) teacher candidate student 2 is 3,$595 ; 3)$ teacher candidate student 3 is 3.82 ; 4 ) teacher candidate student 4 is 3,$685 ; 5)$ teacher candidate student 5 is 3,685 ; and 6 ) teacher candidate student 6 is 3.73 (Table 4 ).

Table 4. The Scores of Learning Implementation

\begin{tabular}{cccc}
\hline \multirow{2}{*}{ The Names of Biology Teacher Candidate } & \multirow{3}{*}{ The Scores } \\
\cline { 2 - 4 } & \multirow{2}{*}{$\mathbf{1}^{\text {st }}$ Expert } & \multirow{2}{*}{$\mathbf{2}^{\text {nd }}$ Expert } & \multirow{2}{*}{ The Average } \\
\hline Teacher candidate student 1 & 3,36 & 3,82 & 3,59 \\
\hline Teacher candidate student 2 & 3,64 & 3,55 & 3,595 \\
\hline Teacher candidate student 3 & 3,91 & 3,73 & 3,82 \\
\hline Teacher candidate student 4 & 3,73 & 3,64 & 3,685 \\
\hline Teacher candidate student 5 & 3,73 & 3,64 & 3,685 \\
\hline Teacher candidate student 6 & 3,82 & 3,64 & 3,73 \\
\hline The Average & 3,69 & 3,67 & 3,68 \\
\hline
\end{tabular}

The information:

$1,0-2,0=$ enough

$2,1-3.0=\operatorname{good}$

$3,1-4,0=$ very good

\subsection{The Scores of Teacher's Self Confidence Support}

The mean score for confidence support of biology teachers is 3,778 (or very good category) in which the average scores of teacher's self confidence Support of each student biology teacher candidate are: 1) teacher candidate student 1 is 3,$835 ; 2$ ) teacher candidate student 2 is 3,$665 ; 3$ ) teacher candidate student 3 is 3,835 ; 4) teacher candidate student 4 is 3,665 ; 5) teacher candidate student 5 is 3,835 ; and 6 ) teacher candidate student 6 is 3,835 (Table 5). 
Table 5. The Scores of Teacher's Self Confidence Support

\begin{tabular}{lccc}
\hline & \multicolumn{3}{c}{ The Scores } \\
\cline { 2 - 4 } The Names of Biology Teacher Candidate & \multirow{2}{*}{$\mathbf{1}^{\text {st }}$ Expert } & $\mathbf{2}^{\text {nd }}$ Expert & \multirow{2}{*}{ The Average } \\
\hline Teacher candidate student 1 & 4 & 3,67 & 3,835 \\
\hline Teacher candidate student 2 & 4 & 3,33 & 3,665 \\
\hline Teacher candidate student 3 & 4 & 3,67 & 3,835 \\
\hline Teacher candidate student 4 & 4 & 3,33 & 3,665 \\
\hline Teacher candidate student 5 & 4 & 3,67 & 3,835 \\
\hline Teacher candidate student 6 & 4 & 3,67 & 3,835 \\
\hline The Average & 4 & 3,557 & 3,778 \\
\hline The information: & & & \\
1,0 - 2,0 = enough & & & \\
$2,1-3.0=$ good & & & \\
$3,1-4,0=$ very good & & &
\end{tabular}

The pedagogical ability of biology teacher candidate students has implemented the correct 2013 curriculum. It is known that science learning should be conducted in scientific inquiry to cultivate the ability to think, work and act scientifically as well as communicate it as an important aspect of life skills. Therefore, the science learning in Junior High School emphasizes the provision of direct learning experiences through the use and development of process skills and scientific attitudes [19]. This should be supported by confidence as a teacher.

\section{Conclusion}

Based on the analysis of the research data, it can be concluded that the pedagogical ability of biology teacher candidate students is in very good category $(\dot{x}=3.77$ scale 4$)$. Meanwhile, based on the self evaluation assesment of the biology teacher candidate students is in good category ( $x=3.87$ scale 5). However, the use of ICT-based learning media is in sufficient category ( $\dot{x}=2.2$ scale 5$)$.

Based on the above conclusions, the suggestions are: 1) for the biology education program as an institution that will produce biology teacher candidate, it should improve the curriculum, especially the integration of ICT in every learning, and 2) it should provide wider and continuous opportunity to the biology teacher candidate students so that they can learn more about the material / contents of science-biology and integrated ICT pedagogy in every learning activity.

\section{Acknowlegment}

Researchers would like to thank to the Ministry of Research, Technology and Higher Education of the Republic of Indonesia who has funded this research in 2018. 


\section{References}

The Partnership for $21^{\text {st }}$ Century Skills. $21^{\text {st }}$ Century Skills, Education \& Competitiveness: A Resource and Policy Guide. (Online) http://www.21 $1^{\text {st }}$ centuryskills.org (2008).

The Partnership for 21st Century Skills. Framework for $21^{\text {st }}$ Century Learning. Washington, DC. (Online) http://www.P21.org (2008).

Kemendikbud. Tantangan, Kebijakan dan Program Menuju Guru Profesional. (Kemendikbud RI: Jakarta, 2010).

BSNP. Paradigma Pendidikan Nasional Abad XXI. (Badan Standar Nasional Pendidikan: Jakarta, 2010).

Undang-Undang RI Nomor 14 Tahun 2005 tentang Guru dan Dosen.

Munandar, K., M. Ibrahim, \& L. Yuanita. International Conference on Education (IECO) Proceeding, LPPM, University of Muhammadiyah Jember, Vol. 1, July 2016, pp. 534-543 (2016).

Guerra, C., A. Moreira, and R.M. Vieira. To Wards the Definition of a Teacher Education Program for the Use of ICT Tools in Science Teaching and Learning. (University of Aveiro: Aveiro, Portugal, 2009).cguerra@ua.pt

Alev, N. Journal of Turkish Science Education, Volume 1, Issue 1, July 2004, pp. 3-20 (Online) http://www.tused.org

Nicholas, Z. \& K. Michail. Grek Primary Students'Atitudes Towards The Use Of ICT For Teaching Natural Sciences. (University of Crete, Faculty of Education, Department of Preschool Education: Yunani, 2011), pp. 264-268. The Research Committee of University of Crete (ELKE) http://www.elke.uoc.gr/

Sorgo, A., T. Verčkovnik and S. Kocijančič. Eurasia Journal of Mathematics, Science \& Technology Education, 6(1), 37-46 (2010).

Munandar, K. \& T. Huda. International Conference on Educational Research and Development (ICERD 2015) UNESA Surabaya-Indonesia, December $5^{\text {th }}$, 2015. ISBN: 978-979-028-799-0 http://icerd.unesa.ac.id

Munandar, K., M. Ibrahim, And L. Yuanita. Paper on The $1^{\text {st }}$ International Conference on Educational Innovation (ICEI) 2017, Universitas Negeri Surabaya, Indonesia, October 14, (2017). 